\title{
OAK WOOD INHABITING FUNGI AND THEIR EFFECT ON LIGNIN STUDIED BY UV MICROSPECTROPHOTOMETRY
}

\author{
Leila Karami ${ }^{1}$, Jörg Fromm ${ }^{1}$, Gerald Koch ${ }^{1}$, Olaf Schmidt ${ }^{1,}$, Uwe Schmitt \\ In memoriam of Dr. Manfred SCHWANNINGER
}

\begin{abstract}
Decayed-wood samples were collected from a naturally-infected bridge made of Quercus robur. Fruiting bodies of the white-rot basidiomycetes Hymenochaete rubiginosa and Stereum hirsutum were sampled. The white-rot fungus Fuscoporia ferrea and the secondary saprobiont Mycena galericulata were identified from the rotten wood by means of rDNA-ITS sequencing. The topochemistry of lignin degradation within individual cell-wall layers was determined by cellular UV-microspectrophotometry (UMSP) at $278 \mathrm{~nm}$ wavelength. Increased delignification occurred in compound middle lamella regions (CML), secondary wall layers of fibres (S2), longitudinal and ray parenchyma cells as well in vessels. The highest lignin content at initial and medium decay was recorded in the CML, whereas in advanced decay secondary wall layers of the vessels exhibited the highest content of residual lignin. In all stages of degradation, the $\mathrm{S}_{2}$ layers of fibres had the lowest lignin amount.
\end{abstract}

Keywords: Oak wood degradation, fungi, rDNA-ITS sequencing, lignin content, UVmicrospectrophotometry.

\section{INTRODUCTION}

Wood degradation occurs through brown-, white- and soft-rot fungi (Eaton and Hale 1993, Schmidt 2006). White-rot predominates in hardwoods (Gilbertson 1980). It is divided into simultaneous white rot and selective delignification (Liese 1970, Nilsson 1988). In simultaneous rot, carbohydrates and lignin are almost uniformly degraded at the same time and similar rate (Rayner and Boddy 1988, Eriksson et al. 1990). In selective delignification, lignin is preferentially degraded, whereas cellulose and hemicelluloses are degraded only at the late stage of attack resulting in a separation of individual cells from one another (Blanchette 1980, Blanchette 1984, Rayner and Boddy 1988).

Traditionally, fungi are identified by their fruiting bodies or other characteristics, such as rhizomorphs (Schmidt 2006). Identification may be difficult if only mycelium or rotten wood is present. Therefore, molecular methods are used (e.g. Schmidt 2006). To identify fungal species, sequencing of the Internal Transcribed Spacer (ITS) of rDNA is commonly applied (Johannesson and Stenlid 1999, Schmidt and Moreth 2002, Högberg and Land 2004, Schmidt et al. 2012). The ITS sequences of many wood- and tree-rot fungi have been deposited in public DNA databases. To identify fungi, the BLAST (Basic Local Alignment Search Tool) program compares the sequence of an unknown fungus with those of deposited sequences. 
Hardwood lignin is composed mainly of guaiacyl and syringyl units. Lignin distribution, content and composition have a significant influence on decay resistance (Frankenstein and Schmitt 2006). Faix (1991) investigated the main categories of lignin, G type, GS type, and HGS type, using FT-IR spectroscopy.

Ultraviolet microspectrophotometry (UMSP) is a reliable technique for direct investigation of lignin distribution in the various layers of wood cell walls (Fergus et al. 1969). UV absorbance spectra use maxima around 212 and $280 \mathrm{~nm}$ (Sarkanen and Hergert 1971). Fergus and Goring (1970a, b) studied the lignin content of fibres and vessels in birch tissue. Localisation of lignins in individual cell wall layers has been also analyzed by Saka and Goring (1988). Lignin and phenolic extractives in woody tissue were examined at $278 \mathrm{~nm}$ by Koch and Kleist (2001), Koch (2004) and Koch and Grünwald (2004). Bauch et al. (1976) studied lignin degradation patterns of white-, brown- and soft-rot fungi, Kleist and Seehann (1997) and Schmidt et al. (1997) of white-rot decay and Irbe et al. (2006) of brown-rot. Brown- and soft-rot in Sapelli wood were topochemically investigated by Kleist and Schmitt (2001). Brown-rot decay in Pinus sylvestris sapwood was studied by Rehbein and Koch (2011) and bacterial degradation of $P$. sylvestris harbour foundation piles by Rehbein et al. (2012). Frankenstein and Schmitt (2006) examined the lignin distribution patterns of wound-adjacent xylem fibres by using electron microscopy and UMSP.

White-, brown- and soft-rot fungi as well as staining fungi have been found in wooden bridges (Schmidt and Huckfeldt 2011), as also in the currently investigated bridge (Karami et al. 2013). The objective of the present study using this wood was to provide information on fungi colonizing naturally infected wood of Quercus robur and to characterize the degradation in the different cells and wall layers. Therefore, rDNA-ITS sequencing was used for fungal identification and UMSP for topochemical lignin detection in the secondary walls of vessels, fibres, ray parenchyma and longitudinal parenchyma as well as in the CML regions of the decayed wood tissue.

\section{MATERIALS AND METHODS}

\section{Sampling}

Samples of ca. $15 \mathrm{~cm}$ length were collected in 2011 from the deck of a bridge made of oak wood (Quercus robur L., European oak). The bridge of $18 \mathrm{~m}$ length and $2.2 \mathrm{~m}$ width, built in 1998 for pedestrians and cyclists, crosses the river Bille between Hamburg and Schleswig-Holstein. Some parts of the bridge showed severe decay on the deck and at the railing (Lerche 2010).

\section{Fungi}

Fruiting bodies growing on the bridge wood were identified according to Jahn et al. (2005). To identify fungi growing inside the rotten wood, a molecular technique was used (Schmidt et al. 2012): Small wood chips were taken from the interior of the wood with a flamed forceps. Total DNA of the chips, DNA from wood and interior fungi, was extracted with the DNeasy Plant Kit (Qiagen, Hilden, Germany). The ITS region of fungi was amplified by PCR (Qiagen Taq Core Kit) using a PCR primer which adheres preferentially to the DNA of basidiomycetes. PCR products were electrophoresed, purified using the QIAquick PCR Purification Kit (Qiagen) and sequenced in both directions by Eurofins MWG Operon (Ebersberg, Germany). Obtained sequences were assigned to their fungal names by using the BLAST program of the DNA databases for sequence comparison with deposited sequences. 


\section{Light microscopy and ultraviolet microspectrophotometric analysis (UMSP)}

Transverse and radial sections from healthy and decayed tissue were prepared with a sliding and ultra-microtome. Sliding microtome sections were stained with aqueous safranine, subsequently with aqueous astra-blue at room temperature, embedded on glass slides with glycerol and examined with an Olympus BX51 light microscope equipped with a digital camera (Olympus DP 70).

For UMSP, small wood blocks $\left(1 \times 1 \times 5 \mathrm{~mm}^{3}\right)$ of decayed tissue were selected from different specimens of the bridge. The samples were dehydrated in a graded series of acetone, embedded in Spurr's epoxy resin (Spurr 1969) and polymerised at $70{ }^{\circ} \mathrm{C}$ for 24 hours. Semi-thin $(1 \mu \mathrm{m})$ sections were prepared with a diamond knife, transferred to quartz microscope slides, embedded in non-absorbing immersion oil and covered with a quartz cover slip. These sections were also examined by light microscopy. The topochemical analyses were carried out with a Zeiss UMSP 80 and TIDAS MSP 800 (j\&m Analytics) microspectrophotometer. The photometric point measurements were performed with a spot size of 1 $\mu \mathrm{m}^{2}$ between $220 \mathrm{~nm}$ and $400 \mathrm{~nm}$ wavelength. The programs LAMWIN ${ }^{\circledR}$ (Zeiss) and TIDASDAQ ${ }^{\circledR}$ (J\&M Analytics) used for this analysis record and evaluate the spectra of the lignified cell walls. These point measurements provide a semi-quantitative determination of lignin content. Each measurement was repeated 15 times at each spot (not previously illuminated by UV light) for individual wall layers, i. e., $\mathrm{S}_{2}$ layers of the secondary wall (fibre, vessel, longitudinal parenchyma and ray parenchyma) and CML regions, respectively.

\section{RESULTS AND DISCUSSION}

\section{Investigated bridge and fungi}

The bridge made of Quercus robur wood showed severe degradation after only 13 years in service, particularly in the deck and railings (Figure 1). Although laboratory resistance tests with basidiomycetous monocultures classify European oak as a durable timber species (Durability Class 2) according to EN 350-2 (CEN 1994), this was neither attested by laboratory soil box tests (DC 5) nor in field studies in ground (DC 5) and above ground (DC 4) (Brischke et al. 2009).

The timber surface of the attacked areas revealed the typical thin layer of soft rot, whereas the middle area was white-rotten. Brown-rot decay was not observed. Four basidiomycetes were identified. Hymenochaete rubiginosa (Dicks.: Fr.) Lév. and Stereum hirsutum (Willd.: Fr.) S.F. Gray were detected by their fruiting bodies. Hymenochaete rubiginosa is a common fungus growing on used wood of Quercus species. Stereum hirsutum inhabits dead hardwoods including oak (Breitenbach and Kränzlin 1986). Two rDNA-ITS products were obtained by PCR and were sequenced. The BLAST program identified them, each with $99 \%$ homology, as Fuscoporia ferrea (Pers.) G. Cunn., which produces white-rot in deciduous and coniferous trees, and as the secondary saprobiont Mycena galericulata (Scop.) Gray, which grows on already decayed wood. The rot type is often related to the wood group. White-rot fungi occur frequently on hardwoods, while most brown-rot fungi affect softwoods (Schmidt 2006). An earlier investigation found H. rubiginosa and S. hirsutum on the same bridge (Lerche 2010). Dinger (1997) investigating 84 wooden bridges in Hamburg identified two brown-rot fungi and four white-rot species, including H. rubiginosa. A nine year survey of wood bridges in North Germany (Schmidt and Huckfeldt 2011) revealed several basidiomycetes, among them $M$. galericulata and $S$. hirsutum.

Figure 1 shows the investigated bridge (left) and a detail with fruiting bodies growing on the deck (right). 


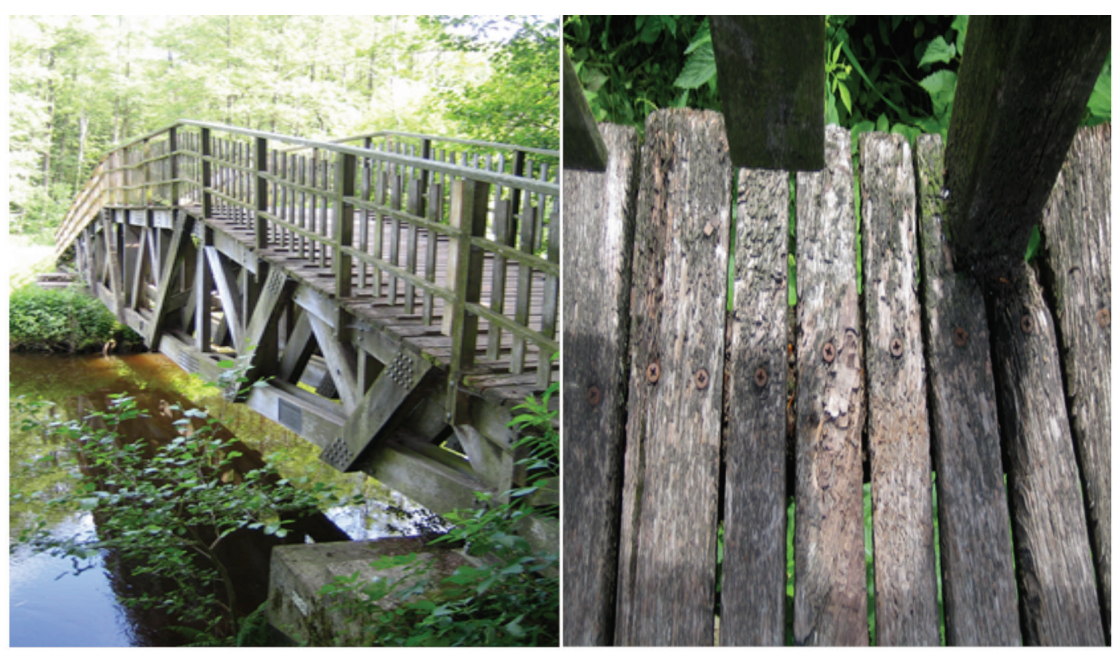

Figure 1. Investigated bridge and detail with fruiting bodies (Lerche 2010).

\section{Light microscopy}

Light microscopy revealed two distinct types of white-rot degradation. In figure $2 \mathrm{a}$, initial colonization is shown by hyphae $(\mathrm{H})$ in the lumen of the fibres penetrating through the adjacent cell wall. In figure $2 \mathrm{~b}$, parts of the tissue are heavily degraded. The cell wall becomes thinner till total cell degradation results in a hollow characteristic of simultaneous white rot. In figure $2 \mathrm{c}$, some cells exhibit degradation in the middle lamella/primary wall region between fibres, being a sign of selective delignification.

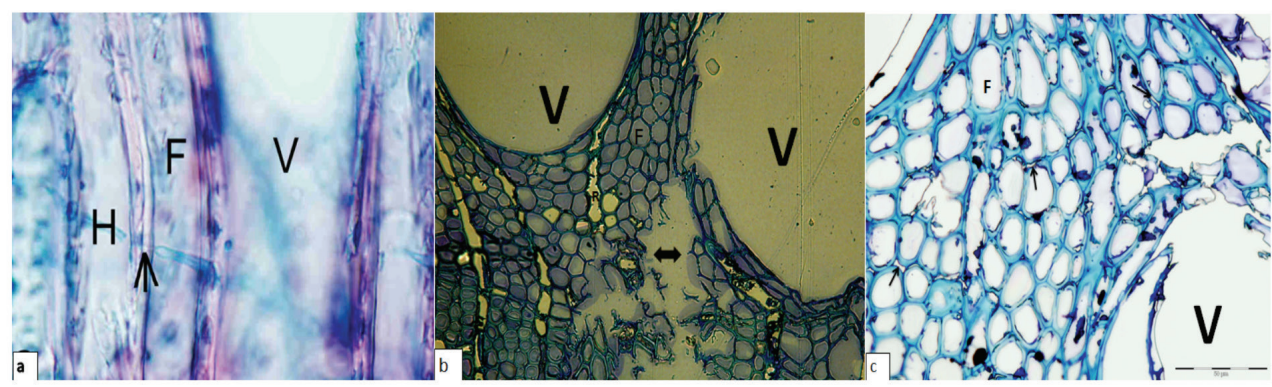

Figure 2. Light microscopy of infected Quercus robur wood: a. Radial section with initial attack and hyphae $(\mathrm{H})$ penetrating $(\rightarrow)$ the fibre cell wall; $b$. Transverse section with simultaneous white $\operatorname{rot}(\leftrightarrow)$; c. Transverse section with selective lignin degradation in the middle lamella/primary region

$$
(\rightarrow) . \mathrm{H}=\text { hypha, } \mathrm{F}=\text { fibre, } \mathrm{V}=\text { vessel, } \mathrm{R}=\text { ray. }
$$

\section{Ultraviolet microspectrophotometric analysis (UMSP)}

UMSP measurements were done for healthy tissue (control) and three different degradation stages (initial, medium and advanced decay) within a wavelength range of $\lambda_{220 \mathrm{~nm}}$ to $\lambda_{400 \mathrm{~nm}}$. Figure 3 shows as an example for the different stages the UV absorbance spectra of the lignin distribution in the compound middle lamella region (CML) of fibre and secondary wall $\left(\mathrm{S}_{2}\right)$ of fibre, longitudinal and ray parenchyma as well vessel) of control tissue (top) and advanced stage of decay (bottom). 


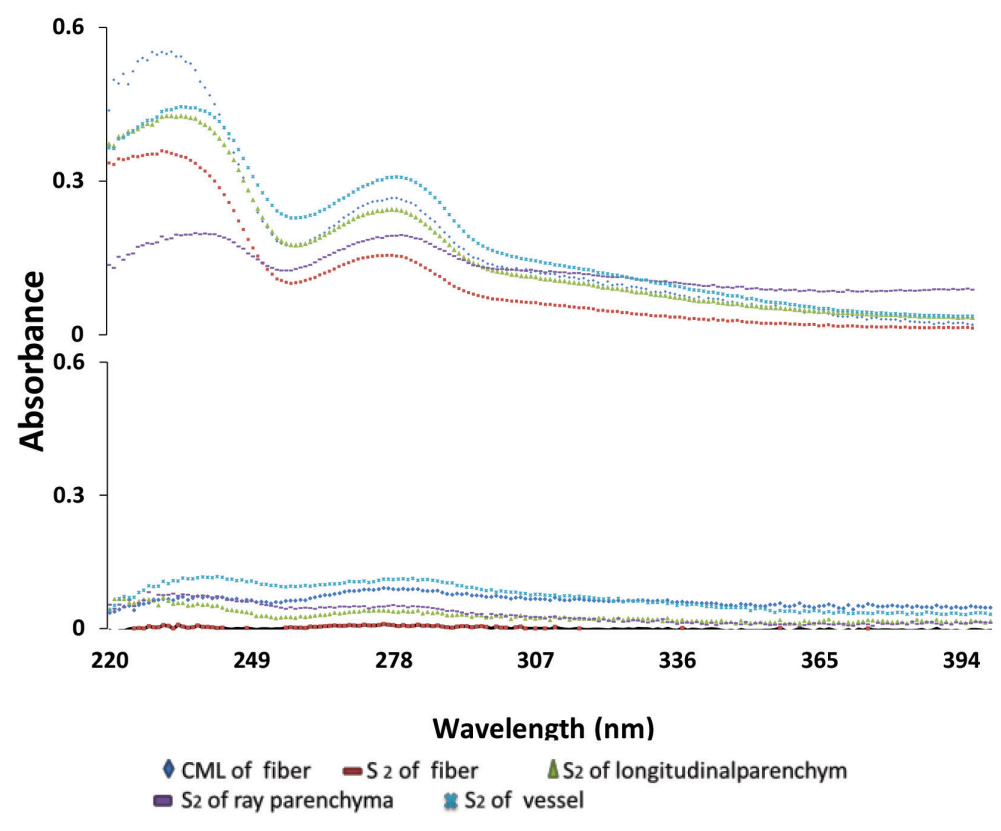

Figure 3. Lignin absorbance spectra of control Quercus robur wood (top) and at advanced stage of decay (bottom).

The analyses of the spectra of control tissue (Figure 3 top) revealed the typical absorbance behaviour of hardwood lignin with a distinct maximum at $278 \mathrm{~nm}$ and a local minimum at about $250 \mathrm{~nm}$. The highest absorbance values were observed in the $S_{2}$ layers of vessels (abs $278 \mathrm{~nm} \mathrm{0,31)} \mathrm{and} \mathrm{the} \mathrm{lowest}$ values in the $\mathrm{S}_{2}$ of fibres $(0,15)$, respectively. High absorbance values in the compound middle lamella between fibres and the $\mathrm{S}_{2}$ layers of the vessel can be explained by the presence of strongly absorbing guaiacyl-lignin. The spectrum of the $\mathrm{S}_{2}$ layer of ray parenchyma cells shows a slightly lower absorbance than that of longitudinal parenchyma cells.

In the initial stage of decay (Table 1), the highest absorbance values were recorded in the compound middle lamella of fibres (abs $278 \mathrm{~nm} 0,19)$ and the lowest values in the $S_{2}$ layers of fibres $(0,05)$. Absorbance values in ray and longitudinal parenchyma cells were nearly similar $(0,17)$, whereas those in the compound middle lamella of fibres $(0,19)$ and $\mathrm{S}_{2}$ layers of vessels $(0,18)$ were almost the same.

In comparison to the initial stage of decay, the highest absorbance values in medium stage of decay (Table 1) occurred in the compound middle lamella of fibres (abs $278 \mathrm{~nm} \mathrm{0,16),} \mathrm{and} \mathrm{the} \mathrm{lowest} \mathrm{values} \mathrm{in} \mathrm{the}$ $\mathrm{S}_{2}$ layers of fibres $(0,02)$. The spectrum of the $\mathrm{S}_{2}$ layer of ray parenchyma cells showed higher absorbance compared with those of longitudinal parenchyma cells. The absorbance in compound middle lamella regions of fibres $(0,16)$ and $S_{2}$ layers of vessels $(0,14)$ was almost the same like in initial decay stage.

As compared to the initial and medium stages of decay, the lowest absorbance in advanced stages of decay (Figure 3 bottom) occurred in the $\mathrm{S}_{2}$ layers of fibres $(0,01)$. The highest absorbance was found in the $\mathrm{S}_{2}$ layers of vessels $(0,11)$, whereas in initial and medium stages of decay, the highest absorbance was recorded in the CML of fibres. The absorbances in ray parenchyma cells $(0,05)$ and longitudinal parenchyma cells $(0,04)$ were of the same magnitude. In an advanced stage of decay, CML regions of fibres showed a distinctively lower absorbance than those in the $\mathrm{S}_{2}$ layers of vessels and thus a higher level of decay. 
Table 1 summarizes the detected absorbance values at $278 \mathrm{~nm}$ in control and decayed oak wood of the individual cell wall layers (CML of fibre and $\mathrm{S}_{2}$ of fibres, longitudinal and ray parenchyma as well as vessels).

Table 1. Logarithmic absorbance values at $278 \mathrm{~nm}$ of control and decayed oak wood.

\begin{tabular}{|l|l|l|l|l|}
\hline Cell wall & control & initial decay & medium decay & advanced decay \\
\hline CML fibre & $0,26 \pm 0,013$ & $0,19 \pm 0,005$ & $0,16 \pm 0,002$ & $0,09 \pm 0,002$ \\
\hline$S_{2}$ fibre & $0,15 \pm 0,008$ & $0,05 \pm 0,001$ & $0,02 \pm 0,001$ & $0,01 \pm 0,001$ \\
\hline $\begin{array}{l}S_{2} \text { longitudinal } \\
\text { parenchyma }\end{array}$ & $0,22 \pm 0,012$ & $0,17 \pm 0,002$ & $0,08 \pm 0,002$ & $0,04 \pm 0,001$ \\
\hline$S_{2}$ ray parenchyma & $0,19 \pm 0,012$ & $0,17 \pm 0,009$ & $0,11 \pm 0,003$ & $0,05 \pm 0,001$ \\
\hline$S_{2}$ vessel & $0,31 \pm 0,013$ & $0,18 \pm 0,003$ & $0,14 \pm 0,002$ & $0,11 \pm 0,002$ \\
\hline
\end{tabular}

$\pm=$ standard deviation

Absorbance values in the compound middle lamella of fibres in the three stages of degradation were 0,$19 ; 0,16$ and 0,09 but those for the $\mathrm{S}_{2}$ layer of fibres 0,$05 ; 0,02$ and 0,01 respectively. The process of degradation in the longitudinal parenchyma $(0,17 ; 0,08$ and 0,04$)$ was initially higher than in ray parenchyma $(0,17 ; 0,11$ and 0,05$)$. The $\mathrm{S}_{2}$ layer of vessels in initial, medium and advanced decay showed absorbance values 0,$18 ; 0,14$ and 0,11 , respectively.

Fergus and Goring (1970a, b) found in birch that the secondary wall layers of fibres and ray parenchyma cells contains more syringyl than guaiacyl units. This distribution was also found in this study. In all stages of degradation, the $\mathrm{S}_{2}$ layers of fibres had the lowest lignin amounts. The reason for this decrease is the fact that syringyl lignin is less resistant to white rot fungi than guaiacyl lignin, as also described by Lewis and Yamamoto (1990) and Faix et al. (1985). In addition, when compared with ray and longitudinal parenchyma cells in decayed oak, the secondary wall of fibres showed a more distinct damage (Table 1). It can therefore be assumed that the secondary walls of ray and longitudinal parenchyma cells are encrusted with aromatic compounds and extractives, leading to an increased resistance against fungi (Hillis 1987). Longitudinal parenchyma cells showed a slightly lower absorbance than ray parenchyma cells, probably the consequence that ray parenchyma cells deposited more aromatic compounds and extractives which can resist fungal attack. In hardwoods, the secondary walls of vessels and cell corner regions contain more guaiacyl lignin (Musha and Goring 1975). The absorbance of guaiacyl residues is about four times higher than that of syringyl residues (Musha and Goring 1975). In both healthy and infected oak wood, the $\mathrm{S}_{2}$ layers of vessels and CML regions of fibres showed a generally higher absorbance as compared with those of the secondary walls of fibres, ray parenchyma and longitudinal parenchyma cells. This can be explained by the presence of the strongly absorbing guaiacyl-lignin in the $\mathrm{S}_{2}$ layers of vessels and CML regions of fibres. Consequently, the $\mathrm{S}_{2}$ layers of vessels and CML regions of fibres were less decayed as compared with the secondary wall layers of fibres, ray parenchyma and longitudinal parenchyma cells. However, the CML regions of fibres showed a higher level of decay than the $\mathrm{S}_{2}$ layers of vessels. This probably depends on the fact that lignin in the CML regions of fibres is more susceptible to degradation by fungi than lignin in the $\mathrm{S}_{2}$ layers of vessels. 


\section{CONCLUSION}

This study on a rotten oak wood bridge demonstrated the presence of some white-rot fungi responsible for decay and the suitability of UV-microspectrophotometry to study the distribution of lignin on a subcellular level in decayed Quercus robur wood. In particular, the high resolution of the point measurements (spot size of $1 \mu \mathrm{m}$ ) enabled a direct evaluation of the local lignin content and provided fundamental information on the topochemistry of lignin. Using this technique, fine differences in the delignification of individual cell wall layers could be analysed.

\section{REFERENCES}

Bauch, J.; Seehann, G.; Fitzner, H. 1976. Microspectrophotometrical investigations on lignin of decayed wood. Material and Organisms 3: 141-152.

Blanchette, R.A. 1980. Wood decomposition by Phellinus (Fomes) pini. Canadian Journal of Botany 58: 1496-1503.

Blanchette, R.A. 1984. Screening wood decayed by white-rot fungi for preferential lignin degradation. Applied \& Environmental Microbiology 48: 647-653.

Breitenbach, J.; Kränzlin, F. 1986. Pilze der Schweiz. vol. 2., Mykologia, Luzern, 416p.

Brischke, C.; Welzbacher C.R.; Rapp, A.O.; Augusta, U.; Brandt, K. 2009. Comparative studies on the in-ground and above-ground durability of European oak heartwood (Quercus petrea Liebl. and Quercus robur L.). European Journal of Wood Products 67: 329-338.

Dinger, B.C. 1997. Pilz- und Insektenbefall an Holzbrücken im Hamburger Raum. Diploma thesis, University of Hamburg, 131p.

Eaton, R.A.; Hale, M.D.C. 1993. Wood. Decay, pests and protection. Chapman \& Hall, London, 546p.

European committee standardization. CEN. 1994. Durability of wood and wood-based products - Natural durability of solid wood - Part 2: European committee standardization, Brussels.

Eriksson, K.E.; Blanchette, R.A.; Ander P. 1990. Microbial and enzymatic degradation of wood and wood components. Berlin, Heidelberg, New York: Springer. 407p.

Faix, O.; Mozuch, M.D.; Kent Kirk, T. 1985. Degradation of gymnosperm (guaiacyl) vs. angiosperm (syringyl/guaiacyl) lignins by Phanerochaete chrysosporium. Holzforschung 39: 203-208. 
Faix, O. 1991. Classification of lignins from different botanical origins by FT-IR spectroscopy. Holzforschung 45 (Supplement): 21-27.

Fergus, B.J.; Goring, D.A. I. 1970a. The location of guaiacyl and syringyl lignins in birch xylem tissue. Holzforschung 24: 113-117.

Fergus, B.J.; Goring, D.A.I. 1970b. The distribution of lignin in birch wood as determined by ultraviolet microscopy. Holzforschung 24: 18-124.

Fergus, B.J.; Procter, A.R.; Scott, J.A.N.; Goring, D.A.I. 1969. The distribution of lignin in spruce wood as determined by ultraviolet microscopy. Wood Science and Technology 3: 117-138.

Frankenstein, C.; Schmitt, U. 2006. Microscopic studies on modified wall structure and lignin topochemistry in xylem fibres of poplar after wounding. Maderas- Cienc Tecnol 8(2): 93-106.

Gilbertson, R.L. 1980. Wood-rotting fungi of North America. Mycologia 72: 1-49.

Hillis, W.E. 1987. Heartwood and tree exudates. Springer, New York. 268p.

Högberg, N.; Land, C.J. 2004. Identification of Serpula lacrymans and other decay fungi in construction timber by sequencing of ribosomal DNA - A practical approach. Holzforschung 58: 199-204.

Irbe, I.; Noldt, G.; Koch, G. 2006. Application of scanning UV micro spectrophotometry for the topochemical detection of lignin within individual cell walls of brown-rotted Scots pine (Pinus sylvestris L.) sapwood. Holzforschung 60: 601-607.

Jahn, H.; Reinartz, H.; Schlag, M. 2005. Pilze an Bäumen: Saprophyten und Parasiten, die an Holz wachsen. 3rd edn. Patzer, Berlin, 276p.

Johannesson, H.; Stenlid, J. 1999. Molecular identification of wood-inhabiting fungi in unmanaged Picea abies forest in Sweden. Forest Ecology Management 115: 203-211.

Karami, L.; Fromm, J.; Schmidt, O.; Schmitt, U. 2013. Mycological and microscopical studies on naturally infected Quercus robur wood. Holztechnologie 54: 12-18.

Kleist, G.; Schmitt, U. 2001. Characterisation of a soft rot-like decay pattern caused by Coniophora puteana (Schum.) Karst. in Sapelli wood (Entandrophragma cylindricum Sprague). Holzforschung 55: 573-578. 
Kleist, G.; Seehann, G. 1997. Colonization patterns and topochemical aspects of sap streak caused by Stereum sanguinolentum in Norway spruce. European Journal of Forest Pathology 27: 351-361.

Koch, G. 2004. Topochemical characterization of lignin and phenolic extractives in woody cell walls. Lenzinger Berichte 83: 6-12.

Koch, G.; Grünwald, C. 2004. Application of UV micro spectrophotometry for the topochemical detection of lignin and phenolic extractives in wood fibre cell walls. In: Wood fibre cell walls: methods to study their formation, structure and properties. COST Action E20. pp. 119-130.

Koch, G.; Kleist, G. 2001. Application of scanning UV microspectrophotometry to localise lignin and phenolic extractives in plant cell walls. Holzforschung 55: 563-567.

Lerche, H. 2010. Vorstellung von Maßnahmen zum Schutz von Holzbrücken vor holzzerstörenden Pilzen. Bachelor thesis, University of Hamburg, 65p.

Lewis, N.G.; Yamamoto, E. 1990. Lignin: Occurrence, biogenesis and biodegradation. Annual Review of Plant Physiology and Plant Molecular Biology 41: 455-496

Liese, W. 1970. Ultra structural aspects of woody tissue disintegration. Annual Review of Phytopathology 8: 231-257.

Musha, Y.; Goring, D.A.I. 1975. Distribution of syringyl and guaiacyl moieties in hardwoods as indicated by ultraviolet microscopy. Wood Science and Technology 9: 45-58.

Nilsson, T. 1988. Defining fungal decay types - final proposal. International Research Group on Wood Preservation 1355. 3p.

Rayner, A.D.M.; Boddy, L. 1988. Fungal decomposition of wood: its biology and ecology. Chichester, UK: John Wiley \& Sons, 587p.

Rehbein, M.; Koch, G. 2011. Topochemical investigation of early stages of lignin modification within individual cell wall layers of Scots pine (Pinus sylvestris L.) sapwood infected by the brown-rot fungus Antrodia vaillantii (DC.: Fr.) Ryv. International Biodeterioration \& Biodegradation 65: 913-920 
Rehbein, M.; Koch, G.; Schmitt, U.; Huckfeldt, U. 2012. Topochemical and transmission electron microscopic studies of bacterial decay. Micron 44: 150-158.

Saka, S.; Goring, D.A.I. 1988. Localization of lignin in wood cell walls. In: Biosynthesis and biodegradation of wood components. Ed. T. Higuchi. Academic Press, New York. pp. 51-62.

Sarkanen, K.V.; Hergert, H.L. 1971. Classification and distribution. In: Lignin, occurrence, formation, structure and reactions. Eds. Sarkanen, K.V., Ludwig, C.H. Wiley Interscience, New York. pp. 43-49.

Schmidt, O. 2006. Wood and tree fungi. Biology, damage, protection, and use. Springer, Berlin, 344p.

Schmidt, O.; Huckfeldt, T. 2011. Schäden durch Pilze. In. Ed. Oyen. T. Holz im Außenraum. Bruder-Verlag, Köln, 45-53.

Schmidt, O.; Moreth, U. 2002. Data bank of rDNA-ITS sequences from building-rot fungi for their identification. Wood Science and Technology 36: 429-433.

Schmidt, O.; Gaiser, D.; Dujesiefken, D. 2012. Molecular identification of decay fungi in the wood of urban trees. European Journal of Forest Research 131: 885-891.

Schmidt, O.; Schmitt, U.; Moreth, U.; Potsch, T. 1997. Wood decay by the white-rotting basidiomycete Physisporinus vitreus from a cooling tower. Holzforschung 51: 193-200.

Spurr, A.R. 1969. A low viscosity epoxy resin embedding medium for electron microscopy. Journal of Ultrastructural Research 26: 31-43. 